\title{
SANITARY QUALITY OF SANDS FROM MARINE RECREATIONAL BEACHES OF SÃO PAULO, BRAZIL
}

\author{
Maria Inês Zanoli Sato*; Marisa Di Bari; Claudia Condé Lamparelli; Ana Cristina Truzzi; \\ Maria Cristina L.S. Coelho; Elayse Maria Hachich
}

Companhia Estadual de Tecnologia e Saneamento Básico - CETESB, São Paulo, SP, Brasil

Submitted: April 14, 2004; Returned to authors for corrections: August 12, 2004; Approved: November 17, 2005

\begin{abstract}
A sanitary evaluation of sand and water from 16 beaches of São Paulo State, Brazil, was undertaken during spring of 1997 and summer of 1998. Ninety six samples each of wet and dry sand and seawater were collected and analysed for fecal indicator bacteria. A parasitological examination and Candida albicans analysis were also performed in sand samples and F-specific bacteriophages were determined in seawater. Statistical analysis of the results demonstrated higher concentrations of fecal coliforms and fecal streptococci in dry sand during summer. Correlation analysis indicated a significant relationship between fecal indicator densities in wet sand and seawater. There was a significant correlation between the densities of fecal coliforms and fecal streptococci for both types of sand, and this correlation was higher in wet sand. Cysts and eggs of parasites were detected in $4.2 \%$ of the samples and Candida albicans was isolated in $18 \%$ of the samples. The high concentrations of fecal indicators detected in sand during summer demonstrate that there is a health risk to the users of these recreational areas and suggest the necessity of some criteria for microbiological control. Preventive measures, such as education campaings and some management actions are important precautionary measures.
\end{abstract}

Key words: sand, seawater, recreational areas, fecal indicators, microbiological criteria

\section{INTRODUCTION}

Recreational area quality is mainly concerned with water, but in recent years some studies dealing with microbiological quality of sand have been published, $(4,7,9,10,11,14,17,18)$. The sand of beaches behaves as a passive element of cumulative pollution and can become contaminated by garbage, animal dejects or water itself carrying pathogenic microorganisms and parasites. The presence of total and fecal coliforms, Escherichia coli and fecal streptococci in beach sand, and the relationship of their counts to adjacent waters have comprised a significant area of research with apparently contradictory results (19).

Recreational water of the São Paulo State beaches is evaluated only by fecal coliforms analysed on a weekly basis. As studies dealing with the microbiological quality of these sands are scarce, and an evaluation from 1984-1985 revealed high levels of fecal contamination, including pathogenic parasites in some beaches of the São Paulo State Coast (17), it has been decided to perform a new assessment of these sites. This study aimed also to support the São Paulo State Coastal Water Monitoring Program and future regulations.

Although some other authors have focused their studies in non-fecal pathogens, such as Staphylococcus aureus and Pseudomonas aeruginosa, which can also be responsible for swimmer's illness, this work was primarily concerned with fecal indicator bacteria. Since national or international standards or guideline values for microbiological quality of sands are not available, the results were evaluated taking into account quality criteria proposed by Mendes et al. (9) for fecal coliforms, fecal streptococci and Candida albicans. A parasitological examination of the sand was also performed, as faeces from pets and sewage can contaminate it. In order to verify whether water quality could influence wet sand quality, seawater was also analysed for fecal coliforms, enterococci and F-specific bacteriophages.

*Corresponding Author. Mailing address: CETESB - Companhia Estadual de Tecnologia e Saneamento Básico. Av. Frederico Hermann Jr. 345, 05489-900, São Paulo, Brasil. Tel.: (+5511) 3030-6541; Fax (+5511) 3030-6982; E-mail: mariaz@ cetesbnet.sp.gov.br 


\section{MATERIALS AND METHODS}

\section{Sampling}

Samples were collected from five beaches of the North Coast (N1 - N5) and from eleven beaches from the South Coast of São Paulo State (S1-S11) (Table 1). From each one of these 16 collection sites, 3 samples of dry sand, wet sand and seawater were collected during the dry season (spring of 1997, three samplings in September, October and November) and during the rainy season (summer of 1998, three samplings in January, February and March), amounting to 288 samples. These beaches are being regularly monitored in a recreational water quality program and were selected due to the high number of bathers and poor microbiological water quality.

Water samples were collected in sterile $250 \mathrm{~mL}$, wide mouth, plastic bottles, according to the APHA Standard Methods (1). In order to perform a representative sampling, $500 \mathrm{~g}$ of sand were collected from a previously delimited area of $2 \mathrm{~m}^{2}$, being composed of five cores of $100 \mathrm{~g}$ taken from the superficial layer $(30 \mathrm{~cm})$ of different regions within this area and pooled in sterile plastic bottles. Dry sand was collected in non flooded areas (above high tide line) and wet sand was sampled in an intermediate area between the dry sand and the seawater (intertidal zone), in sites where bathers could be found. In all instances the samples upon collection were cooled on melting ice and processed within $24 \mathrm{~h}$.

\section{Microbiological and parasitological analysis}

Most probable number (MPN) of fecal coliforms in water and sand was determined using A1 medium (Difco). Enterococci and fecal streptococci analysis were performed in water and

Table 1. Sampling sites - City, code and name of the beach.

\begin{tabular}{ccc}
\hline City & Code & Beach \\
\hline Ubatuba & N1 & Enseada \\
Ilhabela & N3 & Tenório \\
São Sebastião & N4 & Itaguaçú \\
Caraguatatuba & N2 & Arrastão \\
Peruíbe & S1 & Peruíbe \\
Itanhaém & S2 & Sonho \\
Mongaguá & S3 & Central \\
Praia Grande & S4 & Boqueirão \\
São Vicente & S5 & Itararé \\
& S6 & Milionários \\
Santos & S7 & Boqueirão \\
& S8 & Ponta da Praia \\
Guarujá & S9 & Pitangueiras \\
Bertioga & S11 & Enseada \\
\hline
\end{tabular}

sand by the membrane filtration technique (ME/EIA agar - Difco) and multiple tube technique (azide-dextrose broth), respectively, according to the APHA Standard Methods (1). Membrane filtration technique (MCA agar) was also employed to determine C. albicans in the sand (8). Sand analysis were performed as follows : Sand $(200 \mathrm{~g})$ was agitated in $1,800 \mathrm{~mL}$ of dilution water, prepared according to APHA Standard Methods (1) for approximately 1 minute. After allowing sand grains to settle, the supernatant was inoculated in broth or filtered according to Most Probable Number and Membrane Filtration techniques. Sand samples were examined for helminth eggs and protozoan cysts by centrifugation followed by flotation $\left(33 \% \mathrm{ZnSO}_{4}\right.$ solution) and sedimentation techniques (15). F-specific bacteriophages were determined in seawater by the direct plating method using E. coli $\mathrm{Hfr}$ as the bacterial host (5).

\section{Statistical analysis}

Data were transformed logarithmically for subsequent analysis. Analysis of the variance (ANOVA/F-Fisher test) and the Multiple Comparison Test of Bonferroni (12) were used to study fecal coliform and fecal streptococcus/enterococcus data. ANOVA model included three factors: Environment (dry and

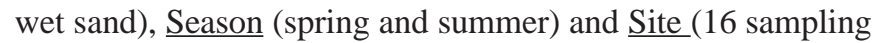
sites) and the interactions between these factors.

A binomial comparison of proportions using a hypothesis test was used to determine whether the non-compliance with the guideline values for fecal coliforms and fecal streptococci proposed by Mendes et al. (9) was significantly different according to environment and season.

Pearson's correlation coefficient was determined for fecal coliform and fecal streptococcus/enterococcus values in both environments. The significance level selected was 5\%. The statistical package used for analysis was Statgraphics Plus for Windows 2.1.

\section{RESULTS}

\section{Fecal Coliforms}

Geometric means of fecal coliform concentrations for the 16 collections sites, during spring and summer, are presented in Fig. 1. Higher levels of bacteria were detected in dry sand and in summer, ranging from $10^{3}$ to $10^{6} \mathrm{MPN} / 100 \mathrm{~g}$. Analysis of the variance of these data (Table 2) showed that the three factors

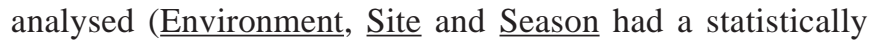
significant effect on fecal coliforms at 95\% confidence level $(\mathrm{p}$-value $<0.05))$. The interaction of Environment and Site was also significant at this level.

According to Bonferroni's test, average values were statistically higher in summer than in spring, and also higher in dry sand than in wet sand. Bacterial concentrations showed no significant differences at the 16 collection sites (Fig. 2), but in some beaches (N2 and N3) higher values were detected in wet 


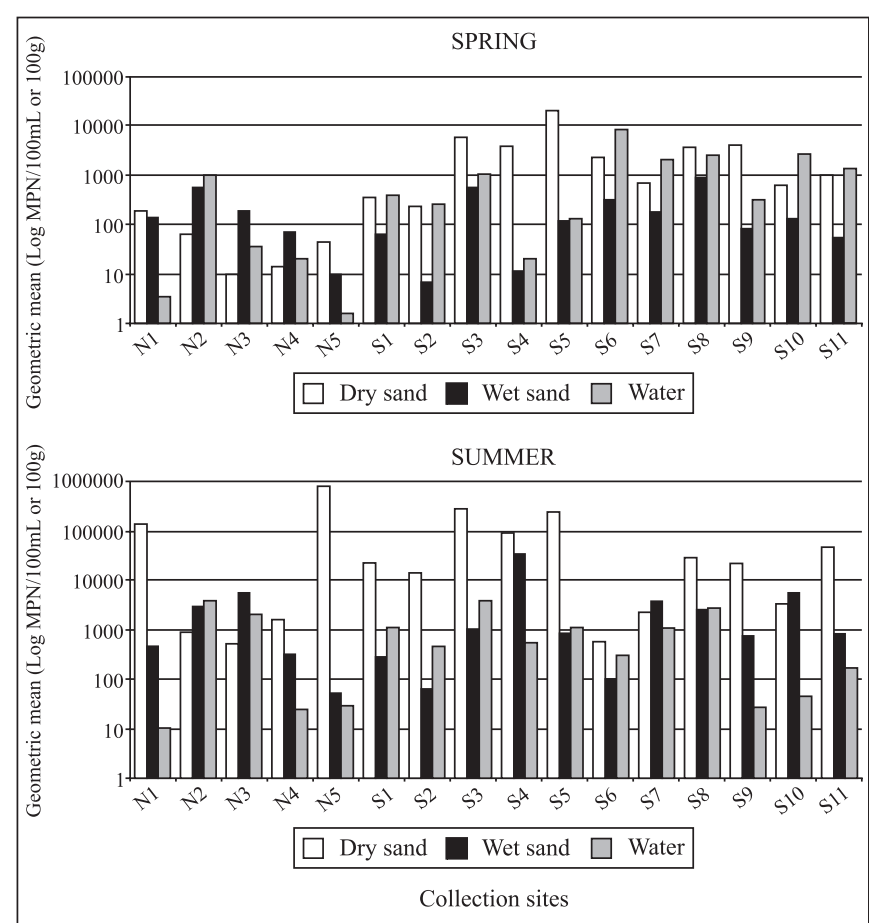

Figure 1. Geometric mean of fecal coliform concentrations at each collection site during spring and summer.

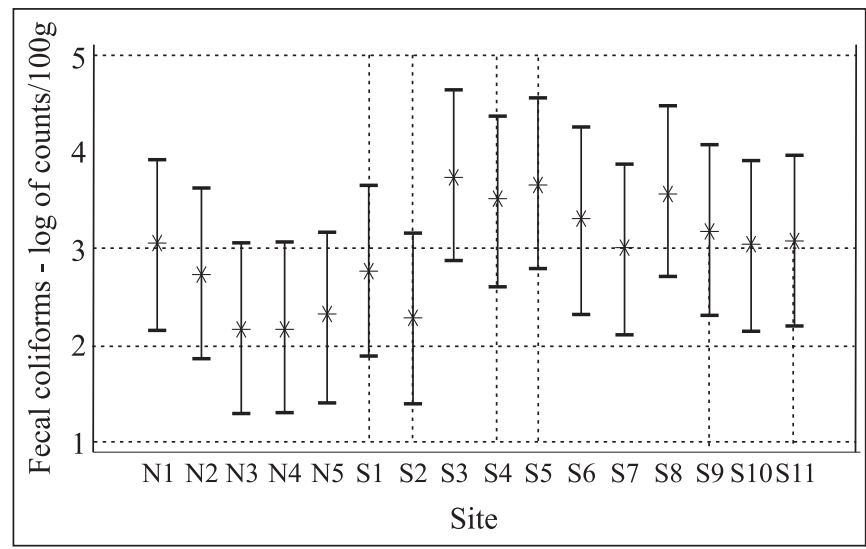

Figure 2. 95\% confidence interval (Tukey's method) for fecal coliform counts determined in dry and wet sand collected at 16 different sites, during spring and summer.

sand, whereas in other ones (S7 and S10) there was only a slight difference or no difference at all (N4) between the average data (Fig 3).

Fecal coliform concentrations remained below Mendes' (9) proposed guideline value $\left(10^{5} / 100 \mathrm{~g}\right)$ during the spring, whereas in summer this limit was surpassed in $12 \%$ of samples from some beaches of North and South Coast. Also, a higher number
Table 2. ANOVA for fecal coliform concentrations in dry and wet sand at 16 collection sites, sampled on three occasions, in spring and summer

\begin{tabular}{crc}
\hline Source & F-ratio & p-value \\
\hline Main Effects & & \\
A: Environment & 30.940 & 0.000 \\
B: Site & 2.180 & 0.009 \\
C: Season & 57.030 & 0.000 \\
Interactions ab & 2.650 & 0.001 \\
\hline
\end{tabular}

Table 3. Compliance of sand quality with the fecal coliform and streptococci values proposed by "Portuguese Guideline for Microbiological Quality of Sand".

\begin{tabular}{|c|c|c|c|c|c|}
\hline \multirow[t]{2}{*}{ Factor } & \multicolumn{2}{|c|}{$\begin{array}{l}\text { Non-compliance } \\
\text { values }\end{array}$} & \multicolumn{2}{|c|}{$\begin{array}{l}\text { Compliance } \\
\text { values }\end{array}$} & \multirow{2}{*}{$\begin{array}{l}\text { Proportion } \\
\text { test } \\
\text { ge }\end{array}$} \\
\hline & \multicolumn{4}{|c|}{ Number Percentage Number Percentage } & \\
\hline \multicolumn{6}{|c|}{ FECAL COLIFORMS } \\
\hline SEASON & & & & & $\mathrm{p}<0.01$ \\
\hline Spring & 0 & 0 & 144 & 100 & (significant) \\
\hline Summer & 17 & 12 & 124 & 88 & \\
\hline \multicolumn{5}{|c|}{ ENVIRONMENT } & $\mathrm{p}<0.01$ \\
\hline Dry sand & 14 & 15 & 81 & 85 & (significant) \\
\hline Wet sand & 3 & 3 & 92 & 97 & \\
\hline \multicolumn{6}{|c|}{ FECAL STREPTOCOCCI } \\
\hline SEASON & & & & & $\mathrm{p}<0.01$ \\
\hline Spring & 11 & 8 & 133 & 92 & (significant) \\
\hline Summer & 31 & 22 & 113 & 78 & \\
\hline \multicolumn{5}{|c|}{ ENVIRONMENT } & $\mathrm{p}<0.01$ \\
\hline Dry sand & 32 & 33 & 64 & 67 & (significant) \\
\hline Wet sand & 9 & 9 & 87 & 91 & \\
\hline
\end{tabular}

of dry sand samples were not in compliance with these guidelines compared to the wet sand samples (15\% versus $3 \%)$. These results were statistically significant $(\mathrm{p}<0.01)$ as could be demonstrated by the test of proportions (Table 3 ).

\section{Fecal streptococci}

Geometric means of fecal streptococcus densities for the 16 collections sites are presented in Fig. 4. Higher levels of bacteria were detected in dry sand and in summer, ranging from $10^{3}$ to $10^{5} \mathrm{MPN} / 100 \mathrm{~g}$. ANOVA revealed that Environment and Season had a statistically significant effect on fecal streptococcus concentrations ( $\mathrm{p}<0.05)$, whereas the remaining factors and interactions were not significant (Table 4). 


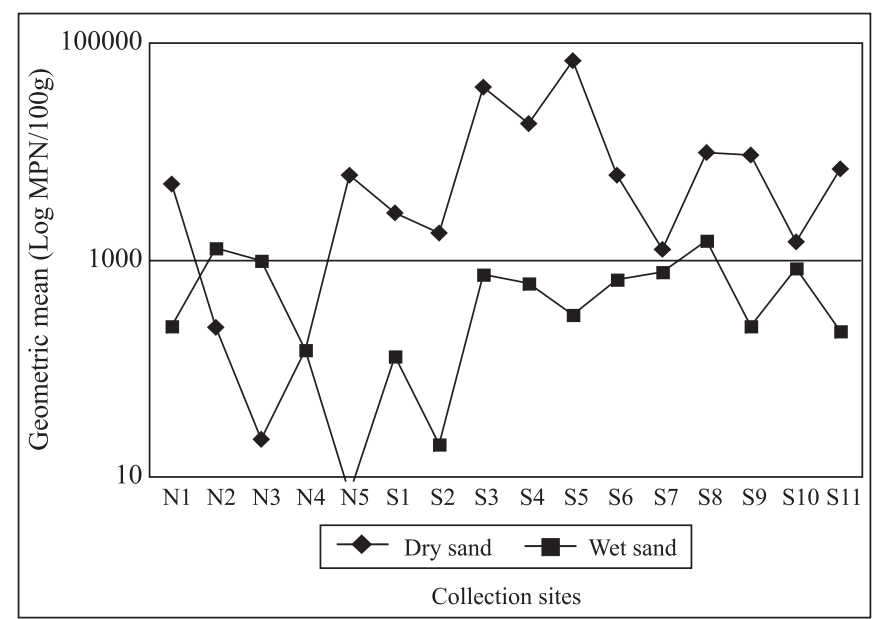

Figure 3. Geometric means of fecal coliform counts determined in dry and wet sand collected at 16 sites during spring and summer.

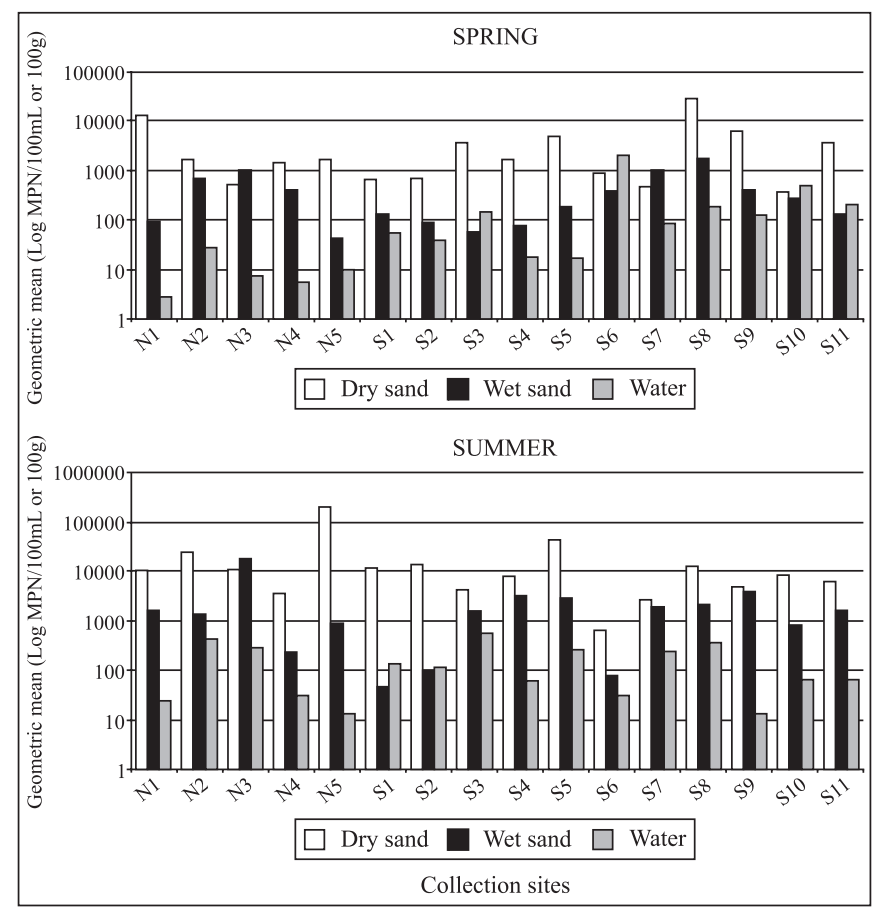

Figure 4. Geometric mean of fecal streptococcus concentrations at each collection site during spring and summer.

Bonferroni's test showed that, bacterial average values were statistically higher in summer than in spring, and also higher in dry sand than in wet sand, the same pattern observed for fecal coliforms.

Fecal streptococcus densities remained below the proposed Portuguese guideline value $\left(10^{4} \mathrm{MPN} / 100 \mathrm{~g}\right)$ for $67 \%$ and $91 \%$ of dry and wet sand samples, respectively. Taking into account the season, a higher percentage of samples collected during
Table 4. ANOVA for fecal streptococcus concentrations in dry and wet sand at 16 collection sites, sampled on three occasions, in spring and summer.

\begin{tabular}{lcc}
\hline \multicolumn{1}{c}{ Source } & F-ratio & p-value \\
\hline Main Effects & & \\
A: Environment & 38.430 & 0.000 \\
B: Season & 19.370 & 0.000 \\
\hline
\end{tabular}

spring (92\%) than that ones collected during summer (78\%) were in compliance with this guideline. The test of proportions demonstrated that these differences were statistically significant $(\mathrm{p}<0.01)$ (Table 3).

\section{Correlation analysis}

The concentrations of fecal coliforms (FC) and fecal streptococci (FE) in seawater, dry and wet sand were compared by correlation analysis. There was a significant correlation for both bacterial indicators between wet sand and seawater ( FC: $r=0.39, p<0.001 ; F E: r=0.25, p<0.01$ ), but not between dry sand and seawater. The densities of these indicators correlated well between dry $(r=0.55, p<0.01)$ and wet $(r=0.67 ; p<0.01)$ sand, with this correlation being stronger in wet sand.

\section{Parasites}

Parasites were detected in four samples of sand during summer: Entamoeba coli (2 cysts in one sample of dry sand and 1 cyst in another), Strongyloides stercoralis (one egg and one larva in a wet sand sample), Giardia lamblia (two cysts in a dry sand sample). In the spring the parasites were isolated from four samples of dry sand: Hymolepis diminuta (one egg in one sample), Ancylostomidae ( 8 eggs and three larva in one sample, 1 larvae and 4 eggs in another) and Giardia lamblia (one cyst in one sample).

\section{Candida albicans}

The frequency and percentage of isolations of this yeast, as well as the range of concentrations, are presented in Table 5. A more elevated number of positive samples for the yeast was detected in dry sand during spring.

\section{F-Specific Bacteriophages}

These viruses were detected more frequently at South Coast beaches during both seasons, but in summer there were more beaches in non-compliance with the guideline value of $200 \mathrm{PFU}$ (plaque forming units) $/ 100 \mathrm{~mL}$ proposed by Ministry of Health and Welfare (13). At North Coast sites, these microorganisms were seldom observed, and only twice in concentrations surpassing $200 \mathrm{PFU} / 100 \mathrm{~mL}$. The frequency and percentage of isolations of this virus, as well as the range of concentrations are presented in Table 6. 
Table 5. Frequency, percentage of positive results and range of concentrations for Candida albicans isolated in dry and wet sand, during spring and summer

\begin{tabular}{ccccccccc}
\hline & \multicolumn{3}{c}{ Dry sand } & \multicolumn{2}{c}{ Wet sand } & Total \\
\cline { 2 - 8 } Season & $\mathrm{n}^{\text {o }}$ & $\%$ & $\begin{array}{c}\text { Range of } \\
\text { C. albicans densities } \\
(\text { CFU*/mL) }\end{array}$ & $\mathrm{n}^{\circ}$ & $\%$ & $\begin{array}{c}\text { Range of } \\
\text { C. albicans densities } \\
(\text { CFU/mL) }\end{array}$ & $\mathrm{n}^{\circ}$ & $\%$ \\
\hline Spring & 13 & 27 & $0->600$ & 11 & 23 & $0-40$ & 24 & 25 \\
Summer & 4 & 8 & $0-3800$ & 7 & 15 & $0-10$ & 11 & 11 \\
\hline Total & 17 & 18 & - & 18 & 19 & - & 35 & 18 \\
\hline
\end{tabular}

$* \mathrm{CFU}=$ colony forming units.

Table 6. Frequency, percentage of positive results and range of concentrations for F-specific bacteriophages isolated in water during spring and summer.

\begin{tabular}{cccc}
\hline Season & $\mathrm{n}^{\mathrm{o}}$ & $\%$ & $\begin{array}{c}\text { Range of F-Specific } \\
\text { Bacteriophages (PFU*/100mL) }\end{array}$ \\
\hline Spring & 20 & 42 & $0-254$ \\
Summer & 22 & 46 & $0-2000$ \\
\hline Total & 42 & 44 & - \\
\hline
\end{tabular}

$* \mathrm{PFU}=$ plaque forming units.

\section{DISCUSSION}

Waterborne gastroenteritis outbreaks in swimmers occurs more often in summer, when the number of tourists at beach resort areas is higher and consequently there is an increase of sewage discharge to the seawater. Also this pollution becomes worse due to the contribution of rainfall events. A cause-effect relationship between fecal pollution of recreational waters and these outbreaks is well established (16). In recent years there has been also some concern about the microbiological contamination of the sand, due to either garbage from recreational use of the beaches or solids deposited by the tides, and also about actual and potential health risks. However, at present, epidemiological evidence for such risks has not been found (19).

In this study, higher levels of fecal indicator bacteria, coliforms and streptococci, were observed in dry sand during summer. The potential health risk associated with the exposure to the contaminated sand should also be higher in summer, especially for the people, usually children, who stay there longer. Bathers should be informed about this risk and told how to prevent it. Higher levels of bacteria in dry sand, that it is not under the influence of the tides, may indicate that the main source of fecal contamination is not the seawater, but instead the heavily polluted water of creeks and runoff. It may also indicate that the bacteria attached to the particulate matter survive longer in the sand. Lower levels of fecal bacteria in wet sand probably occur due to a "washing effect" of the seawater that seems to play more of a dilution rather than a contamination role. Statistical analysis indicated a high correlation between fecal bacterial densities in wet sand and seawater, but not between dry sand and seawater. Fecal coliform and streptococcus concentrations correlated well in dry and wet sand.

Other researchers have also found this kind of relationship between sand and water pollution. Aulicino et al. (2), studying fecal contamination of shoreline sands in Italy observed larger numbers of fecal pollution indicator bacteria in the sand than in seawater, with bacteria in the sand being detected in concentrations from 1 to 30 times greater than in the corresponding seawaters. Ghinsberg et al. (7) detected more elevated concentrations of fecal bacteria in the sand of Tel Aviv beaches (samples were collected 2-3m inwards from the shoreline). By contrast, the results obtained by Chabasse $e t$ al . (3) showed that the sand was less polluted than the water of the Lac Du Maine, a nautical centre comprising a complete sports complex and a bathing beach in western France. Papadakis et al. (14) found very low levels of fecal bacteria both in water and wet sand of two beaches in Greece. Neither Chabasse nor Papadakis observed any differences in fecal contamination according to the season.

In summer there have also been more beaches that surpassed Mendes' (9) quality criteria for fecal coliform and streptococci, as demonstrated by a statistical proportion test, a greater percentage of the non-compliance occurring due to fecal streptococci than to fecal coliforms. Streptococci can survive longer in the environment than coliforms, but it is also possible that this fecal contamination originates from animals (pets and birds). According to Mendes et al. (10), fecal streptococci can be a better indicator organism for sand than fecal and total coliforms.

Regarding Candida albicans, a similar percentage of positive results was obtained in dry and wet sand $(17 \%$ and 18\%). Ghinsberg et al. (7) have found $35 \%$ of C. albicans 
positive sand samples in Tel Aviv coast, whereas Mendes et al. (11) could isolate this yeast in only one of the twelve beaches included in an evaluation performed at Lisboa and Vale do Tejo coastal area. The detection of the yeast in sand samples should be considered relevant, since skin and mucous membrane infections could result from the contact with $C$. albicans contaminated sand. Brisou (1975), cited by Kay (8), has noted an increase in Thrush infection amongst women holidaying at seaside. Also within this context, parasitic infections due to hookworm should be considered. This study detected only $4.2 \%$ of parasite positive samples, and at low concentrations, but Sanchez et al. (17) detected $12.9 \%$ of helminth eggs, some of these samples presenting densities as high as 115 Ancylostomidae eggs in 100g of sand. Esterre and Agis (6), during a parasitological investigation in the sand of some beaches from Guadeloupe could isolate larvae of hookworms of animal origin, sometimes in important quantity as well as eggs of Toxocara sp. According to these authors, clinical cases of cutaneous Larva migrans are frequent in the West Indies, contrary to cases of visceral Larva migrans.

The results of this study showed that fecal contamination in the sand during summer was higher than during spring and highest in dry sand. These data suggest the necessity of some criteria for microbiological control. According the World Health Organization (19) preventive measures, such as education campaings and some management actions are important precautionary measures.

\section{RESUMO}

\section{Qualidade sanitária de areia de praias recreacionais em São Paulo, Brasil}

Foi realizada uma avaliação sanitária das águas e areias de 16 praias do litoral do Estado de São Paulo, Brasil, durante a primavera de 1997 e verão de 1998. Cento e noventa e duas amostras de areia seca e úmida, e 96 amostras de água do mar, foram coletadas e analisadas quanto à presença de bactérias indicadoras de contaminação fecal. Também foram realizados exames parasitológicos e análises de Candida albicans nas amostras de areia, e a determinação de bacteriófagos Fespecíficos nas amostras de água. A análise estatística dos resultados demonstrou concentrações mais elevadas de coliformes e estreptococos fecais na areia seca, durante o verão. Observou-se uma correlação significativa (Pearson) entre as concentrações de coliformes fecais e estreptococos fecais para os dois tipos de areia, correlação esta mais elevada na areia úmida. Ovos e cistos de parasitas e C. albicans foram detectados em $4,2 \%$ e $18 \%$ das amostras, respectivamente. As elevadas densidades dos indicadores de contaminação fecal detectadas nas areias durante o verão mostram a necessidade de orientar-se adequadamente a população a respeito das doenças veiculadas pela areia e das medidas preventivas necessárias, bem como de buscar-se um critério adequado para monitorar esse risco.

Palavras-chave: areia, água do mar, áreas de lazer, indicadores de contaminação fecal, critérios microbiológicos

\section{REFERENCES}

1. APHA. Microbiological examination of water. In: Standard Methods for the Examination of Water and Wastewater, 19a ed., Washington, APHA, AWWA, WEF, 1995.

2. Aulicino, F.A.; Volterra, L.; Donati, G. Faecal contamination of shore-line sands. Boll. Soc. It. Biol., 61(10), 1469-1475, 1985.

3. Chabasse, D.; Laine, P.; Simitzis, L.F.; Martineau, B.; Hourchis, E.E.; Beacaud, J.P. Sanitary study of surface water and of the beach of a water sports and leisure complex. J. Hyg., 96, 393-401, 1986.

4. Codinachs, M.R.; Viñas, A.M.I.; Escobar, M.D.F.; Perez, F.F. Contaminación microbiológica de la arena de las playas de la ciudad de Barcelona. Rev. Sanid. Hig. Publica, 62, 1537-1544, 1988.

5. DeBartolomeis, J.; Cabelli, V.J. Evaluation of an Escherichia coli Host Strain for Enumeration of F Male-Specific Bacteriophages. Appl. Environ. Microbiol, 57(5), 1301-1305, 1991.

6. Esterre, P.; Agis, F. Les nématodes du sable des plages en Guadeloupe: Problèmes de santé publique associés. Bull. Soc. Pathol. Ex., 78, 7178, 1985.

7. Ghinsberg, R.C.; Bar Dov, L.; Rogol, M.; Sheinberg, Y.; Nitzan, Y. Monitoring of selected bacteria and fungi in sand and seawater along the Tel Aviv coast. Microbios, 77, 29-40, 1994.

8. Kay, D. Recreational water quality management, Vol. 1: Coastal waters. Ellis Horwood Limited, 1992, London, 256 p.

9. Mendes, B.; Nascimento, M.J.; Oliveira, J.S. Preliminary characterisation and proposal of microbiological quality standard of sand beaches. Water Sci. Technol, 27(3-4), 453-456, 1993.

10. Mendes, B.; Urbano, P.; Alves, C.; Lapa, N.; Morais, J.; Nascimento, J.; Oliveira, J.F.S. Sanitary quality of sands from beaches of Azores islands. Water Sci. Technol, 35(11-12), 147-150, 1997.

11. Mendes, B.; Urbano, P.; Alves, C.; Morais, J.; Lapa, N; Nascimento, J.; Oliveira, J.F.S. Fungi as environmental microbiological indicators. Water Sci. Technol., 38(12), 155-162, 1998.

12. Miller, R.G. Simultaneous Statistical Inference ( $2^{\text {nd }}$ ed.), New York: Springer Verlag, 1981, p.67.

13. Ministry of Health and Welfare. Guidelines for Canadian Recreational Water. Canadian Government Publishing Centre. Ottawa, Canada, 1992, 101p.

14. Papadakis, J.A.; Mavridou, A.; Richardson, S.C.; Lampiri, M.; Marcelou, U. Bather-related microbial and yeast populations in sand and seawater. Water Res., 31(4), 799-804, 1997.

15. Pessoa, S.B.; Martins, A.V. Parasitologia Médica. Guanabara Koogan S/A, Rio de Janeiro, 1982, 1002p.

16. Prüss, A. A review of epidemiological studies from exposure to recreational waters. Int. J. Epidemiol., 27, 1-9, 1998.

17. Sanchez, P.S.; Agudo, E.G.; Castro, F.G.; Alves, M.N.; Martins, M.T. Evaluation of the sanitary quality of marine recreational waters and the sand from beaches of the São Paulo State, Brazil. Water Sci. Technol., 18(10), 61-72, 1986.

18. Vieira, R.H.S.F.; Rodrigues, D.P.; Menezes, E.A.; Evangelista, N.S.S.; Reis, E.M.F.R.; Barreto, L.M.; Gonçalves, F.A. Microbial contamination of sand from major beaches in Fortaleza, Ceará State, Brazil. Braz. J. Microbiol., 32, 77-80, 2001.

19. World Health Organization. Guidelines for safe recreational water environments. Volume 1, Coastal and fresh waters. World Health Organization, Geneva, 2003, 215p. 